\title{
POLITICAL CONSEQUENCES OF PACIFIC ISLAND ELECTORAL LAWS
}

\section{Jon Fraenkel}

AT FIRST SIGHT, the Pacific Islands seem like a graveyard for institutional determinist theories regarding the impact of electoral systems on party polarisation. Maurice Duverger's well-known 'sociological law' was that first-past-the-post electoral rules tend to deliver two-party systems. Proportional representation systems were more loosely associated by Duverger with multi-party settings. ${ }^{1}$ Yet in the Pacific, countries using firstpast-the-post systems, such as the Solomon Islands and PNG (1975-2002), have developed multiple-party systems. The proportional representation-using territories of New Caledonia, French Polynesia and Vanuatu have veered towards a two-camp polarisation around the issue of independence. Some first-past-the-post-using democracies, such as Palau and the FSM, have not witnessed the emergence of any party-based system at all. Neighbouring Kiribati, Nauru and Tuvalu have similar styles of loose and fluctuating parliamentary alliances but no election-oriented political parties, despite the first using a two-round electoral system, the second a unique simultaneously tallied preferential voting system, and the third a block-voting system in two-member constituencies. Electoral laws would appear to exert negligible sway over Pacific party systems.

On closer examination, Duverger's theory does shed some light on the direction of electoral incentives in some of the Pacific countries, once hedged with the necessary qualifications and confined to appropriate settings. Negative cases, where electoral laws do not bring about the anticipated party structures are not confined to Oceania. India and Canada, for example, have numerous political parties, but use first-past-the-post electoral systems. Guyana uses a list proportional representation system but has a twoparty centred system, as did Austria from 1945-90. Much of the literature has consequently been aimed at revising Duverger's theories about the impact of electoral laws on party systems, either by emphasising that the critical association is in fact between district magnitude and the number of parties or by specifying the role of intervening variables, such as ethnic heterogeneity or the number of competing issue 
dimensions' to the political process. ${ }^{2}$ It is in situations where a single salient political cleavage (such as labour/ conservative, or Catholic/Protestant) dominates the political order that distinct electoral laws might work in different directions, encouraging or limiting multi-partyism. In Fiji and New Caledonia, those varying electoral pressures on party systems exerted considerable control over the success or failure of compacts aimed at mitigating ethnic conflict.

In most South Pacific nations, the decolonisation issue did not prove an enduring ideological influence over post-independence politics (except in Vanuatu, and, if we include countries still under some kind of colonial rule, New Caledonia and French Polynesia). Class politics nowhere proved a central cleavage regulating post-colonial political organisation, except plausibly on one level within Fiji's Indian community during the 1990s. Nor — again except in ethnically bipolar Fiji — did other issues emerge that stimulated the formation of organisationally robust or durable alliances. In many cases, political parties remain either non-existent or they comprise only fleeting and regularly changing assembly groupings, commanding little loyalty or popular respect. ${ }^{3}$ 'Party politics', to the extent that it exists, is frequently viewed with disdain, and charged with aggravating social tensions that run counter to Pacific traditions of consensus and compromise. Fluidity of parliamentary alignments, and the readiness of MPs to 'cross the floor', ensure a frequent turnover of governments, particularly in western Melanesia but also in Nauru and Kiribati. The Pacific Island states have consequently eminently passed Samuel Huntington's 'two turnover' test of democratic consolidation. ${ }^{4}$ Indeed, they have done so to such a degree that the primary concern is endemic instability rather than the absence of regime change.

During the decolonisation era, colonial authorities frequently anticipated and encouraged the emergence of local political parties, identifying these as a necessary counterpart of the removal of official majorities and post-independence political stabilisation..$^{5}$ Drawing on experience in other parts of the world, analysts suggested that 'the appearance of political parties in a democratic political system tends to be associated with the expansion of the franchise and the introduction of a significant elective element in national decision-making councils'. ${ }^{6}$ Party politics was often viewed as an evolutionary stage and any sign of the crystallisation of fleeting alliances or greater organisational rigour was seen as indicative of its imminent realisation. ${ }^{7}$ The lessons from 20 th century Western Europe or North America, after all, seemed to indicate the universality of partycentred political development, and elsewhere anti-colonial movements and/or labour movements often coalesced into political parties that served as governments-in-waiting and endured after the handover of power. Political parties are consequently frequently deemed indispensable for functioning democracies, to provide linkages between citizens and their representatives and to facilitate collective decision-making. ${ }^{8}$

Influenced by such ideas, contemporary Pacific governments have introduced a range of reforms designed to strengthen political parties. Fijis 1995-96 Constitutional Review Commission, for example, gave a high priority to the 'recognition of the role of political parties' in its choice of institutions capable of achieving 'multi-ethnic government'. Parties, it was hoped, would serve as agents of moderation and inter-ethnic 
conciliation, and, to accomplish this, they were provided with considerable control over the transfer of preference votes. ${ }^{10}$ As part of the new electoral system adopted in 1997-98, a split-format ballot paper was introduced, with an 'above-the-line' section enabling voters to indicate their support for party-endorsed preference schedules. The hope was that this would enhance political parties' bargaining capacity and simultaneously encourage inter-ethnic deals on politically sensitive policy issues. Constitutional rules governing the post-election formation of cabinets in Fiji also potentially had repercussions for the party system. All parties with more than 10 per cent of seats were entitled to a proportional share of ministerial portfolios, implying a considerable disincentive for smaller parties and independent candidates.

PNG's Organic Law on the Integrity of Political Parties and Candidates (OLIPPC) is the most ambitious of the contemporary party engineering projects in the Pacific. MPs are given financial incentives to join political parties, and are required to toe the party line during critical votes in Parliament, including those on motions of no confidence, constitutional amendments and budgets. PNG's reforms, and the underlying concerns that inspire these, also influence the reform-oriented discourse elsewhere in the region. In Sämoa, the governing Human Rights Protection Party in 1995 facilitated the passage of legislation obliging candidates to specify their allegiance with the objective of enhancing the electoral significance of political parties. Sämoa, Fiji and New Zealand adopted laws against partyhopping, with a view to strengthening party parliamentary organisation and diminishing government instability. ${ }^{11}$ The 'strengthening of parties' is frequently a smokescreen for reforms aimed at consolidating the grip of executives (or incumbent parties). Given the threat of instability associated with recurrent regime change and the often gridlocked nature of governments threatened by 'no confidence' challenges, such reforms (with or without the smokescreen) have often understandably found tacit support among donors and diplomats from neighbouring metropolitan powers.

This chapter surveys the range of electoral system types and party structures across the Pacific Islands and considers the viability of contemporary electoral reforms aimed at strengthening party systems. For each region, the chapter surveys in brief all countries, but focuses in detail on one or two countries in which particularly topical electoral issues arise. As an antidote to the approach of setting up the familiar party-based model, and then examining the extent to which Pacific politics achieves that style of organisation, we examine first the western and northern independent Pacific states where political parties are of least significance, then look at those Polynesian countries where political parties have assumed greater significance before focusing on the most strongly party-centred ethnically bipolar states of Fiji and New Caledonia.

Table 3.1 surveys the types of electoral system used in legislative elections across the region. First-past-the-post systems (used in single-member districts) are the most frequent arrangement, although often combined with a number of block-voting districts (with multiple members), where eligible citizens have as many votes as there are seats. Guam, where citizens have 15 votes to fill 15 places, has the most sizeable of such districts, but Majuro in the Marshall Islands elects five members and tiny Niue has a sixmember island-wide constituency, as well as separate single-member village-based 
constituencies. Vanuatu and Pitcairn Island have multiple-member constituencies combined with only a single vote for each eligible citizen (i.e., single non-transferable vote systems). Kiribati has a multi-member block-vote district system, but uses a second round of voting where necessary. Fiji and PNG have adopted the alternative vote, which involves the redistribution of preference votes, either until majorities are secured (Fiji) or until ballots are exhausted (PNG). ${ }^{12}$ Nauru's preferential system is distinctive, because it uses multi-member constituencies and because all preferences are simultaneously counted. New Caledonia, French Polynesia and Wallis and Futuna use list proportional representation systems for territorial elections. Voters back a single party, and the proportion of candidates elected from that party's list depends on its district percentage of the vote. These countries also have the largest constituencies in the Pacific: for example, 37 members are returned by French Polynesia's Windward Islands (Tahiti and Moorea), and 32 congress members are elected from New Caledonia's Southern Province. All three French territories also participate in metropolitan French elections, which entail a tworound system for legislative and presidential elections.

Table 3.1 also constructs an index for the 'effective' number of parties using an adjusted variant of the widely used Laakso/Taagepera Index combined with data covering distribution of seats by political party recorded in the 2005 Political Parties of the World. The Laakso/Taagepera Index aims at obtaining a meaningful composite number so as to establish whether each country has a two- or a multi-party system. For example, a country with three parties that secure 55 per cent, 45 per cent and 5 per cent of seats is shown as having a 2.2-party system, rather than a three-party system. The results are inevitably as good or as bad as the underlying data, in the sense that for some Pacific states the 'parties' recorded exist merely on paper. ${ }^{13}$ Since party vote shares are impossible to establish meaningfully for the more fluid party systems, the index is calculated using party seat shares. ${ }^{14}$ The standard Laakso/Taagepera Index is not well honed to deal with situations where a large number of independents enter parliament. To handle this, column three removes independents from the calculation while column four indicates the preponderance of the party system. Hence, for example, PNG's 22 parties that secured seats at the 2002 polls (including many single- or two-seat parties), once weighted to yield an adjusted Laakso/ Taagepera measure, suggest a 10-party system, whereas column four tells us that 79 per cent of PNG MPs were affiliated with political parties and that the residual, 21 per cent, were independents.

In terms of the robustness of party political organisation, the Pacific states straddle a range that extends from relatively strongly party-centred polities (such as Fiji and New Caledonia, where bipolar ethnic frictions have, historically, encouraged the emergence of relatively strong party organisations) to no-party or only nominally party-based systems (such as PNG, Solomon Islands, Palau, Nauru and the FSM). Political parties are regularly provided for in Pacific constitutions. Even where they are not envisaged, other legislative provisions might facilitate the emergence of assembly groupings. The cohesion of 'the opposition' is often encouraged, for example, by provisions regarding the establishment of an 'Office of the Leader of the Opposition', and laws regulating the competitive selection of the 'Leader of the Opposition'. In the Solomon Islands, provisions 
Table 3.1: Electoral Systems, Effective Number of Political Parties and Extent of Party Preponderance in Pacific Island Legislative Assemblies.

\begin{tabular}{|c|c|c|c|c|}
\hline Country/Territory & $\begin{array}{c}\text { Electoral } \\
\text { System } \\
(1)\end{array}$ & $\begin{array}{l}\text { Year } \\
(2) \\
\end{array}$ & $\begin{array}{c}\text { 'Effective' } \\
\text { No. Parties } \\
(3)\end{array}$ & $\begin{array}{c}\text { Party } \\
\text { Preponderance } \\
\text { (4) }\end{array}$ \\
\hline American Sämoa (US) & FPP & $\mathrm{N} / \mathrm{P}$ & 0.0 & 0.00 \\
\hline Cook Islands & FPP & 1999 & 2.6 & 1.00 \\
\hline Fed. States of Micronesia & FPP & $\mathrm{N} / \mathrm{P}$ & 0.0 & 0.00 \\
\hline Fiji & AV & 2001 & 2.7 & 0.96 \\
\hline French Polynesia (France) & $\mathrm{LPR}^{1}$ & 2001 & 2.3 & 1.00 \\
\hline Guam (US) & BV & 2002 & 1.9 & 1.00 \\
\hline Kiribati & $\mathrm{TRS}^{2}$ & 1998 & 2.0 & 0.64 \\
\hline Marshall Islands & FPP/BV & 1999 & 1.0 & 0.55 \\
\hline Nauru & STPV & $\mathrm{N} / \mathrm{P}$ & 0.0 & 0.00 \\
\hline New Caledonia (France) & LPR & 1999 & 4.5 & 1.00 \\
\hline Niue & $\mathrm{FPP} / \mathrm{BV}$ & $\mathrm{N} / \mathrm{P}$ & 0.0 & 0.00 \\
\hline Comm. Northern Marianas (US) & FPP & 2003 & 2.5 & 1.00 \\
\hline Palau & FPP & $\mathrm{N} / \mathrm{P}$ & 0.0 & 0.00 \\
\hline Papua New Guinea & FPP & 2002 & 10.0 & 0.79 \\
\hline Pitcairn Island (UK) & SNTV & $\mathrm{N} / \mathrm{P}$ & 0.0 & 0.00 \\
\hline Sämoa & FPP/BV & 2002 & 1.9 & 0.73 \\
\hline Solomon Islands & FPP & 2001 & 3.3 & 0.98 \\
\hline Tonga & FPP/BV & 2002 & $1.0^{3}$ & 0.78 \\
\hline Tuvalu & $\mathrm{FPP} / \mathrm{BV}$ & $\mathrm{N} / \mathrm{P}$ & 0.0 & 0.00 \\
\hline Vanuatu & SNTV & 2004 & 6.9 & 0.85 \\
\hline Wallis and Futuna (France) & LPR & 2002 & 1.8 & 1.00 \\
\hline
\end{tabular}

Sources: Levine, S. and N. Roberts. 2005. 'The Constitutional Structures and Electoral Systems of the Pacific Islands.' Journal of Commonwealth and Comparative Politics, Vol. 43, No. 3., pp. 276-95; Szajkowski, B. (ed.) 2005. Political Parties of the World. 5th edition (1st edition, 1980).

Notes: FPP - first-past-the-post; AV - alternative vote; LPR - list proportional representation; BV - block vote; TRS - Two round system; STPV - simultaneously tallied preferential vote; SNTV - single non-transferable vote; N/P - no party system. The Laakso/Taagepera Index is one minus the sum of squared seat shares, with independents calculated as parties with single seats (Taagepera, R. 1989. Seats and Votes: The Effects and Determinants of Electoral Systems. New Haven: Yale University Press. pp. 78-9). The index shown here is adjusted by excluding independents, and by weighting parties by their share in the total seats secured by parties in assemblies. The party preponderance index (column four) shows party-affiliated MPs divided by total parliamentary membership (with 1.0 conveying an entirely party-centred system and 0.0 indicating an entirely non-party system). Election years are the latest recorded in the 2005 edition of Political Parties of the World.

1 With 30 per cent plurality Seat Bonus.

2 Block vote with second round in several multi-member constituencies.

3 Only the nine universal franchise seats are counted, and, in this context, the Human Rights and Democracy Movement is counted as a political party. 
under the 1978 Constitution for the 'Leader of the Independents', oddly, encouraged the quasi-party-style functioning of reputedly non-aligned MPs. After general elections, independents operate virtually like the country's loosely knit political parties, and come together in the capital, Honiara, to select their own, or back another, candidate for the premiership. Similarly in Sämoa, a Sämoan United Independents Party emerged after the 2001 polls, although laws against post-electoral party formation were used by the Government to declare illegal its subsequent efforts to form a new party together with the major opposition party. As we have seen, legislation aimed at strengthening political parties has been adopted widely across the region, whether it be through direct financial incentives for party-aligned candidates or, indirectly, by 'grace periods', rules prohibiting 'party-hopping' and other restraints on 'no-confidence' votes.

\section{Melanesia}

\section{PNG}

PNG used an optional preferential voting system in elections held in 1964, 1968 and 1972, but then switched to a first-past-the-post system in $1975 .{ }^{15}$ The number of candidates contesting elections subsequently increased at every election, reaching an average of 27 per constituency at the 2002 polls. Numbers of victors obtaining more than 50 per cent of the vote declined, with the majority of MPs being elected on the basis of less than 20 per cent of the vote in 1992, 1997 and 2002. National elections became vehicles for the articulation of clan rivalries, particularly in the Highlands. Parties proved, at most, loose associations, which politicians were readily willing to ditch in pursuit of ministerial portfolios. Customary 'big men' competed for wealth, influence and authority through electoral processes, driven by pecuniary rewards attached to state office-holding. ${ }^{16}$ Whether or not they joined nominal political parties, victors' positions remained highly precarious. More than half of all MPs lost their seats at most elections after independence, with incumbent turnover reaching an all time high of 75 per cent at the 2002 polls.

Inside Parliament, politicians frequently steer clear of political parties, or form fleeting party attachments that play second fiddle to personal advancement. No single party has ever obtained an absolute majority in Parliament. PNG had 10 governments from 1975 to 2002, three of which were dislodged by votes of no confidence. Governments are frequently formed by backroom cabals ('lock-ups'), which proceed to divide among themselves the spoils of office. MPs on the Opposition benches thus have every incentive to, and little institutional inhibition against, plot the next no confidence bid. Many prefer to sit on the 'middle benches', in a twilight position between government and opposition, hoping to secure ministerial portfolios at the next reshuffle. ${ }^{17}$ Instead of yielding the frequently anticipated advantage of strong and stable government (due to seat swings that enhance or magnify narrower vote swings), the first-past-the-post system provides the backdrop for a highly volatile parliamentary set-up, in which unscrupulous and opportunistic 'rubber band' or 'yoyo' politicians prove willing to repeatedly switch allegiances for personal or constituency gain. ${ }^{18}$

As a result, Papua New Guinean reformists have taken steps to strengthen the party system. The OLIPPC was enacted in 2002 and was aimed at strengthening political 
parties via controls over funding and restrictions on party-hopping. Those who contest elections as members of parties receive state financial support. Independents do not. Once a vote has been held for a prime minister, MPs are obliged to follow the party line on budgetary and constitutional votes, and in votes of no confidence. Cases involving MPs who cross the floor or fail to follow the party whip on these issues are heard by an Ombudsman Commission and, if necessary, are referred to a Leadership Tribunal, with the ultimate sanction being the forfeit of seats. New rules are aimed at restricting postelection horse-trading, by giving the party with the largest number of seats the first opportunity to form a government. One consequence, witnessed at the 2002 polls, was a sizeable increase in the official number of political parties, which rose from 12 in 1997 to 43 in 2002, although many of these existed only on paper and failed to obtain a single MP. The rules have proved difficult to implement, and, as in India after the introduction of similar legislation in 1985, much party side-switching continues, either illegally or (where this is sanctioned collectively by a party) legally. ${ }^{19}$

A limited preferential voting system (LPV) was also introduced in PNG, and came into effect in the wake of the 2002 general elections. It was aimed chiefly at avoiding the proliferation of MPs elected on the basis of less than 10 or 20 per cent of the vote. To cast a valid (or formal) ballot, citizens are required to list three candidates in order of preference (incomplete ballots with only one or two preferences marked are to be discarded as invalid or informal). If no candidate gets a majority of first-preference votes, the lowestpolling candidate is eliminated and his or her voters' second-preference votes are redistributed among the remaining candidates. This process of elimination of candidates and redistribution of votes continues until one candidate obtains 50 per cent plus one of valid votes or until ballots are exhausted. PNG's new electoral system is designed to encourage more moderate or conciliatory candidates, who reach out beyond their core bases of support in the hope of obtaining second- or third-preference votes from other communities. Both reforms, in different ways, anticipate and encourage a more issueand/or party-based political culture. Just as the candidate with the broader appeal is anticipated, after the introduction of the LPV, to pick up preference votes outside his or her community, so too the more broadly aligned party MP is to receive financial encouragement under the OLIPPC.

Implicit in the philosophy behind the introduction of the OLIPPC and the LPV was the view that Westminster-style political organisation and the first-past-the-post system were in fact responsible for vote-splintering among numerous candidates, high incumbent turnover and volatile allegiances inside Parliament. ${ }^{20}$ If these are shown to owe their origin to inappropriate electoral laws or the constitutional set-up, then institutional change would appear to be a viable method of broadening the basis of parliamentary representation and stabilising governments. If those features have other origins, the two reforms are likely to do more to change the form, rather than the substance, of PNG politics. Claims that electoral rules were responsible for PNG's hyper-fractionalised party space sit oddly next to the Duvergerian association between plurality rules and a two-party system, suggesting that the ultimate origin of vote-splintering lies elsewhere. Variations in the financial incentive structure made little difference in the past. As Ron May points out in 
Chapter Five of this volume, even a tenfold rise in the PNG nomination fee in 1991 did little to arrest candidate proliferation.

\section{Solomon Islands}

In the Solomon Islands, as in PNG, the political spectrum at the national level lacks the enduring ideological cleavages necessary to facilitate the emergence of a stable party structure, partly because customary leadership systems are so individualised and partly because political allegiances are so localised. The political parties that emerged about the time of independence were loose associations clustered around political leaders such as Solomon Mamaloni and Bartholomew Ulufa'alu. Owing to the spread of parliamentary constituencies and the strength of regional loyalties, governments had to be formed that drew on alliances across the island group, in particular balancing the interests of populous Malaita against those of the Western Province and Guadalcanal. Those parties that did emerge usually lacked branch structures and did not have the kind of regional spread that would assist the formation of governments. Peter Kenilorea, a former civil servant from the Are'are District on Malaita who was initially an avowed opponent of 'party politics' ${ }^{21}$ secured the premiership after elections in 1976 and 1980, although he lacked strong party backing. In 1981, ministerial defections brought down his government. $^{22}$ Archrival Solomon Mamaloni, from Makira, replaced Kenilorea as Prime Minister, and his three terms in office proved critical in shaping the post-independence style of Solomon Islands governance.

As Jeffrey Steeves has shown, the post-colonial Solomon Islands became an arena of so-called 'unbounded politics', based on the weaving together of fragile power bases that drew on personal allegiances. ${ }^{23}$ As in PNG, party attachments proved of limited significance and loyalties changed regularly. MPs' positions were highly precarious, with about 50 per cent losing their seats at each election. Parliamentarians were much less likely to face defeat if they sat on the Government benches, and they were often prepared to abandon party allegiances to achieve that goal. Ministerial portfolios offered access to state funds or other government-controlled public service networks that permitted the forging of 'big man' networks of patronage. A Prime Minister's survival depended on judicious distribution of cabinet portfolios and other state appointments, as well as forging links with powerful local or foreign business interests.

Nevertheless, the Opposition was not entirely 'unbounded' by party or principle. In 1997, a reformist coalition came into office headed by Bartholomew Ulufa'alu. It sought to reduce the country's crippling debt, reduce the rate of log extraction and restructure government finances. From late 1998, however, the Solomon Islands became increasing engulfed in conflict, first on Guadalcanal and then also on Malaita and in the Western Province. On June 5, 2000, the Ulufa'alu Government was overthrown by a 'joint operation' involving the paramilitary wing of the police force and Malaitan militia groups, and replaced by a government under the control of the militia groups. After elections were held in December 2001, a new government, headed by former 'Mamaloni man' Allan Kemakeza, secured office, relying on support from the People's Alliance Party and independents. Both post-coup governments relied on personalised mechanisms for procuring political allegiance, although now with the added need to buy off increasingly 
intransigent militants roaming the streets of Honiara or hanging around with guns outside the Finance Ministry and the Prime Minister's office. Although the Australianled Regional Assistance Mission to the Solomon Islands (RAMSI) arrived in mid-2003, disarmed and arrested most of the militants and took some steps to clean up government finances, Kemakeza served his full term as Prime Minister. Indeed, the stabilisation of the security situation initially strengthened his administration, with a number of former opposition leaders crossing the floor to join the Government.

\section{Vanuatu}

At independence, Vanuatu (formerly the New Hebrides) adopted an electoral system that is often believed to promote intra-party competition. ${ }^{24}$ The single non-transferable vote system (SNTV) allows eligible citizens a single vote, but in multi-member constituencies. ${ }^{25}$ The system has peculiar repercussions for party strategy. Parties must more or less accurately anticipate the extent of their electoral support in each constituency, and, where they are potentially able to secure more than one seat, they need to be capable of directing different groups of voters to support each strategically preferred candidate. If Party A potentially has 78 per cent support in a four-member constituency, it might obtain maximum advantage by fielding three candidates and directing precisely one-third of its potential voters to evenly back each favoured candidate (so that each gets 26 per cent). SNTV is crudely proportional, because Party B, if it has the residual 22 per cent support, is potentially capable of returning one of the four victorious candidates. The system was introduced at the time of Vanuatu's independence in 1980 in order to ensure some representation for the francophone minority, and to prevent a clean sweep in favour of the anglophone Vanua'aku Pati (as would have been likely under a first-past-the-post system). Although only crudely proportional, SNTV does have the advantage of simplicity, and removed the need to divide Vanuatu's ethnically mixed islands into separate constituencies. ${ }^{26}$

For the first 11 years after independence, Vanuatu's two major groupings were the predominantly English-speaking Vanua'aku Pati (VP) and an alliance of francophonebacked parties, the Union of Moderate Parties (UMP). ${ }^{27}$ Despite exceptional ethno-linguistic heterogeneity and allegiances to varying Christian church denominations, the polarising issues of independence and land rights encouraged the temporary advent of a two-party system. Until the 1987 polls, the VP and UMP, taken together, accounted for an increasing share of the national vote, although with VP's share falling and the UMP's share steadily increasing. From then onwards, Vanuatu's two-party system splintered, with numerous rival party groupings emerging and a rising number of successful independent candidates. Owing to the emergence of an increasingly fractionalised party system, coalition governments became a permanent feature from 1991 and there were at least 18 wholesale changes of government between 1991 and $2004 .^{28}$

Whether those splits and that instability are due to the usage of the SNTV system is debatable. SNTV rewards minor parties with concentrated regional bases of support and, potentially, promotes internal party rivalry and splintering. ${ }^{29}$ But the late 1980 s and early 1990s splits that arose in the VP in were the result of top level power struggles between Walter Lini, Barak Sope and the rest of the VP leadership, rather than grassroots-driven splintering due to the incentives arising from the SNTV system. 
$\mathrm{Ni}$-Vanuatu politicians' frequent shifts of allegiance, the willingness of party-aligned MPs to cross the floor and continual real or threatened no-confidence challenges were, after all, characteristic also of neighbouring first-past-the-post-using Melanesian countries. SNTV provided a considerable degree of seats/votes proportionality at elections held in 1979, 1983 and 1987, and only in the subsequent years did it become less effective in this respect. As the number of candidates contesting elections rose, the former disciplined party adjustments to predicted voter base gave way to a free-for-all, with candidates potentially able to secure election on the basis of only a small share of the vote. Despite their distinct electoral systems, this cumulative and self-reinforcing candidate multiplication was common to Vanuatu, Solomon Islands and PNG.

\section{Micronesia}

In most of the North Pacific states that have 'Compacts of Free Association' with the US, plurality-based electoral systems have not triggered the emergence of political parties. The key bases for political organisation in the FSM are the separate states of Chuuk, Pohnpei, Kosrae and Yap, or further subgroupings, but the Federal Assembly is dominated by individual powerbrokers with fluctuating allegiances. ${ }^{30}$ In Palau, the 'Compact of Free Association' with the US and the nuclear-free status question for a time proved strongly polarising issues. The compact was rejected at seven referenda, before being passed in 1993. During the 1980s and early 1990s, loose groupings did come together in support of, and in opposition to, the signing of the compact. Yet, as in the FSM, shifting loyalties were centred on 'family, clan and village ties more than party affiliation', and 'some elected leaders, who do not hold chiefly titles, win and hold office because they are supported by and represent the interests of traditional power structures. ${ }^{31}$ In the two northernmost territories, Guam and the Commonwealth of the Northern Marianas (CNMI), tighter integration with the US encouraged ascendancy of American-style parties.

Of the American-associated Micronesian countries, only the Republic of the Marshall Islands has developed a locally based two-party system. In the wake of the death of long-serving President Amata Kabua, local political struggles culminated in the formation of the reformist United Democratic Party (UDP), which won the 1999 election. ${ }^{32}$ At fresh elections in 2003, the UDP was able to retain office, defeating the Kwajalein and other Ralik chain chiefs, who, for the first time, aligned themselves in a political party, the Ailin Kein Ad. ${ }^{33}$ The renewal of the Marshall Islands' 'Compact of Free Association' with the US in mid-2003 and the issue of 'rental' payments for US usage of Kwajalein Atoll as a missile testing facility, alongside controversies about the decline of chiefly political authority, proved sufficiently polarising to, at least temporarily, bring about the development of a two-party system. ${ }^{34}$

Across the equator to the south, the Kiribati two-round electoral system coupled with a preferential ballot for the presidency was introduced to provide some choice despite the absence of organised party politics. ${ }^{35}$ In the multi-member constituencies, candidates are elected if they obtain the required threshold of valid votes. If not, run-off elections are held for the top candidates. ${ }^{36}$ Political parties initially proved occasional alliances of convenience between national politicians, lacking popular membership and 
regularly fading away. ${ }^{37}$ Only after elections, when MPs gather together on the island of Tarawa did 'the factions behave most like political parties'. ${ }^{38}$ Cleavages between Catholics from the northern islands and Protestants from the south underpinned early post-independence politics, but did not lead to the emergence of confessional parties. ${ }^{39}$ Towards the turn of the century, parties assumed greater institutional coherence, adopting constitutions, establishing party offices, circulating newsletters and retaining a membership outside Parliament. ${ }^{40}$

Nauru's electoral system requires voters to rank all candidates in order of preference in seven two-member constituencies and one four-member constituency, a system that has been compared with that invented by 18th-century French mathematician JeanCharles de Borda. ${ }^{41}$ Voters' first preferences are counted as one, second preferences as a half-vote, third preferences as one-third of a vote, fourth preferences as one-quarter of a vote and so on, dependent on the number of candidates, and all votes are instantly summed with the victor being the candidate with the highest total. Unlike the Borda system, Nauru unusually allots fractional votes even to a candidate who comes last (e.g., the loser in a constituency with eight contestants gets one-eighth of the vote) and voters in multi-member constituencies only have a single vote.

Nauru is most frequently classified as a 'no-party' system. ${ }^{42}$ After independence, traditional leaders, led by Hammer DeRoburt, most of whom were formerly councillors from the Nauru Local Government Council, were elected to the new Parliament, and dominated the country's politics for the next 20 years. ${ }^{43}$ After DeRoburt's defeat in 1989, Bernard Dowiyogo served for six terms, with several breaks, until he was replaced by Rene Harris in March 2001. From then on, the once phosphate-rich territory experienced mounting financial crises and repeated regime change. In 2002 alone, for example, there were seven changes in the presidency.

Against this backdrop, a group calling itself the 'visionaries' eventually toppled the old guard politicians associated with Rene Harris in 2004, after a sequence of legal confrontations and controversies surrounding the role of the Speaker of Parliament. At the 2004 polls, there were few first-count leaders who were dislodged by the counting of lower-order preferences, suggesting that a first-past-the-post system would have yielded similar outcomes. Nauru's electoral system has been described as 'absurdly complex' for such a small country. ${ }^{44}$ Yet much of the discussion about the merits of Jean-Charles de Borda's proposed voting system concerns its application to committee elections. ${ }^{45}$ There is no particular reason why small size should be a deterrent to usage of complex systems. It is when they are applied to mass elections, or where the literacy is low, that elaborate voting rules potentially become troublesome.

\section{Polynesia}

Plurality-based electoral systems also prevail across Polynesia, with the exception of the French-controlled group towards the east. Largely block-vote-based systems exist in Tonga and Tuvalu, whereas Sämoa has a majority of single-member first-past-the-postbased districts with only a few multi-member constituencies. ${ }^{46}$ Tonga's electoral system entitles 'commoners' to elect only nine representatives on a universal franchise. Another nine are returned by the holders of 33 noble titles, ${ }^{47}$ and 12 are nominated by the King. 
The King's nominees to Cabinet sit in the Legislative Assembly, but the Executive is not answerable to the Legislature. Contrary to popular belief, the prevailing seat distribution is not entrenched in the country's 1875 Constitution, and the balance between the different categories of members has witnessed major changes, most notably in 1915 when a revision of the composition of the assembly was aimed at enhancing the power of the monarch over that of the nobility. ${ }^{48}$ Since the 1980 s, a pro-democracy movement has emerged (lately calling itself the Human Rights and Democracy Movement). Pro-reform candidates took eight of the nine universal franchise seats in 2005, and, for the first time, two were allowed to join the Cabinet (and were required to forfeit their universal franchise seats to do so. They instead appeared among the King's nominees).

In Tonga, as in Sämoa, the Cook Islands and Niue, overseas migration is a major influence on domestic politics. About 50 per cent of Tongans and Sämoans reside outside their country, as do the overwhelming majority of Cook Islanders and Niueans. Tiny Niue has about 1,400 residents but about 18,477 migrants living in New Zealand who are not entitled to vote. It has a 20-member Parliament, with 14 members returned from single-member village constituencies and six 'common roll' MPs elected on an islandwide block vote. Party labels designate loose assembly groupings, although these are occasionally thought to be sufficiently robust for 'party politics' to be blamed for exacerbating social tensions. ${ }^{49}$

With a population of less than 10,000, Tuvalu has seven two-member constituencies and one single-member constituency, all of which return members by plurality voting (i.e., the block vote in the two-member districts). ${ }^{50}$ There are no political parties, but both members from each of the seven dual-member constituencies tend to align themselves on the same side during prime ministerial elections. Although close to onethird of Tuvalu's population lives on Funafuti, where the capital is, citizens are obliged to vote on their home islands unless they own land or show evidence of five-years' residence elsewhere. Within Parliament, MPs frequently divide on north/south lines, with most prime ministers coming from the southern part of the group (and most governorgenerals coming from the north). ${ }^{51}$ Despite the absence of a party system, Tuvalu's Parliament has been finely balanced between pro- and anti-government MPs. Between 1999 and 2002, there were four different prime ministers, and parliamentary sessions were frequently cancelled or curtailed to avoid the threat of no-confidence challenges. That instability has generated local debate about introducing laws preventing MPs from switching sides, which, given the absence of parties, would presumably entail members sticking by whichever candidate they backed for the premiership after general elections.

The Cook Islands, with a plurality-based system, developed a two-party system shortly after self-government in 1965. Albert Henry's Cook Islands Party (CIP) controlled government but, during the 1970s, was opposed by the minority Democratic Party, which obtained office after a court ruling concerning electoral irregularities associated with using government funds to finance fly-in migrant voters from New Zealand at the 1978 polls. The CIP recaptured office in 1983, but defections and no-confidence challenges became an increasingly regular feature, encouraged by difficulties in securing parliamentary majorities after the emergence of a third party, the Alliance Party, in the 1990 s. $^{52}$ The 
major electoral system changes during this period were (i) the abolition of block voting in multi-member districts in favour of single-member districts in 1981, a reform that has been claimed to have encouraged 'more parochial politicians', 53 and (ii) the introduction (in 1981) and subsequent abolition (in 2004) of a special seat for overseas voters. Despite having a party-based system, the Cook Islands suffers from the difficulties often attributed to the absence of party politics elsewhere: regular changes of government, fluid allegiances and parliamentary opposition groupings that are too preoccupied with overturning incumbent governments to play much role in scrutinising legislation.

\section{Sämoa}

After independence, Sämoa adopted a plurality-based system involving a mixture of single-member and block-voting two-member constituencies. ${ }^{54}$ The country initially witnessed high levels of MP turnover and no-party-based contests as in many parts of Melanesia. The key difference was in the relationship between electoral processes and customary leadership. In 1961, a popular referendum backed usage of an electoral system in which only matai (chiefs) could vote and stand as candidates. In 1990, another popular referendum supported the introduction of a universal franchise, but retention of the matai-based qualification for candidates. Interestingly, the electoral system became much more competitive and party-based even before the 1990 extension of the franchise. Until the mid-1970s, large numbers of MPs were returned from non-contested constituencies, often based on a rotational principle of villages taking it in turns to fill seats. After the mid-1970s, the number of non-contested seats fell and the number of candidates contesting elections rose rapidly. Similarly, in the initial post-independence years, the premiership proved a unique preserve of tama-a-äiga titleholders from Sämoa's four leading dynasties, who were usually returned without contest in the 1960s. From 1976 onwards, prime ministers were all non-tama-a-äiga titleholders, and the position tended to be filled by majority rule. ${ }^{55}$

After the 1979 polls, a party-based system emerged, first as a result of the rise to power of the Human Rights Protection Party (HRPP), and then because the Opposition also adopted party-style organisation. Despite the HRPP's continuing hold on power throughout the period from 1983 to the present (with a brief exception in 1986-87), party allegiances remained fluid. In 1988, only the last-minute defection of an opposition MP enabled the HRPP to retain its hold on office. In general, the number of successful candidates recorded as affiliated with the HRPP before prime ministerial elections tends to be far lower than that recorded once a new government has been formed. At that point, elected MPs gravitate towards the governing party in search of the rewards attached to office-holding. This process was actively encouraged by the HRPP, which increased the constitutionally allowed number of Cabinet portfolios from eight to 12 in 1991, introduced laws against party-hopping in 2005 and created new 'undersecretary' positions for government backbenchers. ${ }^{56}$

\section{French Polynesia}

French Polynesia, which has a majority Polynesian population and an 11 per cent white population, uses a list ticket system like that in New Caledonia, but in its present form it 
is deliberately not proportional. Gaston Flosse, an ally of French President Jacques Chirac, led the Government from 1991 and, owing to the difficulty in sustaining support for a French loyalist position in the predominantly Polynesian territory, favoured enhanced local autonomy. In the elections of May 7, 2001, his Tahoeraa Huiraatira won 29 seats, whereas the pro-independence Tavini Huiraatira (Union for Democracy) obtained 13 seats, resulting in Flosse serving his fifth term as President. In 2004, Flosse increased the number of seats from 49 to 57 , introduced a 3 per cent threshold, and provided for a 30 per cent seat bonus for the party that received the most votes in each of the six multi-member constituencies, claiming that this would increase the stability of government. ${ }^{57}$

Believing that the new majoritarian electoral laws would enhance his majority, Flosse persuaded President Chirac to dissolve the French Polynesian Territorial Assembly. At the consequent elections, held in May 2004, Flosse again triumphed in the outer islands, particularly the Marquesas and Gambier Islands and the Tuamoto Archipelago - where Catholic allegiances and fears of Tahitian domination over an independent nation encouraged French loyalist affinities. But Tahoeraa Huiraatira was narrowly defeated in the large 37-member Windward Islands constituency by only 390 votes, thus missing out on the critical associated seat bonus. ${ }^{58}$ Tahoeraa Huiraatira consequently failed to secure an absolute majority. Longstanding independence leader Oscar Temaru instead narrowly won the vote for the presidency. In the political battle that followed, Temaru was controversially ousted after a single defection from his Union for Democracy. Flosse regained the presidency, but tried to bolster his one-seat majority by calling fresh elections in the 37-member Windward Islands constituency (after Paris accepted his allegations of electoral irregularities in that constituency at the May 2004 polls). At a consequent by-election, held in February 2005, the Union for Democracy acquired an increased share of the vote, leading to the restoration of the Temaru Government. ${ }^{59}$ Political controversy in French Polynesia came to centre less on the independence question (to be indefinitely postponed) and more on alleged corruption and nepotism under the Flosse Administration.

\section{Ethnically bipolar configurations}

\section{Fiji}

In Fiji, conflict between the 52 per cent indigenous Fijians and 44 per cent Indo-Fijians has centred on electoral outcomes, with constitutional crises (in 1977) and coups (in 1987 and 2000) following the election of governments backed largely by Indo-Fijian voters. Electoral reform has consequently been the most politically sensitive issue in the country since independence.

After colonisation in 1874, ethnic Fijians, who were suffering a catastrophic decline in population, were confined largely to their villages under a 'Fijian administration' governed by customary chiefs. From 1879, more than 60,000 labourers were brought from India as indentured labourers to cut sugar cane. Many stayed, and, after indenture ended in 1916, took up positions as tenant farmers supplying cane to the Colonial Sugar 
Refining Company. As free labourers, living standards steadily improved and Indian population levels began to approach those of the Fijians. Demands for political rights led the colonial authorities to concede Indian elected membership in the Legislative Council in 1929, but from separate communal constituencies. ${ }^{60}$ Subsequent agitation for a 'common roll', closely linked to demands from London- and Kenyan-based Indian organisations with regard to the East African situation, seemed in the Fiji context to entail a bid for political power. In response, local Europeans and colonial officials increasingly allied themselves with indigenous Fijians, an arrangement entrenched due to Fijian military participation during World War II. Fijian population levels had begun to recover from the early 1920s, and local Europeans and colonial officials in the postwar Legislative Council reinvented their role as one of protecting 'Fijian paramountcy' (a doctrine also inspired by the 1920s East African situation).

Only as the dismantling of the colonial order began were the issues of political institutions capable of enabling post-independence democracy addressed. In 1965, the official majority was removed and a 'cross-voting' system was introduced. Registered citizens had four votes each, one of which was in an ethnically reserved franchise constituency for their own 'Fijian', 'Indian' or 'general' candidate. The other three were for 'Indian', 'Fijian' or 'general' candidates, in common roll constituencies. The system was aimed at stimulating the emergence of a centrist Malaysian-style Alliance Party with strong roots in the different ethnic communities. It did not succeed in this objective. No centrist party emerged able to capture substantial support in both communities. Voting remained largely along ethnic lines. From 1970 to 1987, the consequence of having a first-past-the-post system with an ethnically bipolar structure was to encourage formation and retention of single homogenous ethnic parties. As one commentator put it, 'Political success in Fiji [became] ... contingent upon maintaining solidarity in one's own ethnic community while actively promoting disunity among the opposition's. ${ }^{\text {'61 }}$

The largely Fijian- and European-backed Alliance Party retained control of government throughout this period, with the exception of the two elections of April 1977 and 1987. The majoritarian electoral system ensured 'winner-takes-all' outcomes, which were not conducive to power-sharing arrangements. In 1977, the newly emergent Fijian Nationalist Party (FNP) acquired 25 per cent of the indigenous vote (in a manner that was notably disobedient to first-past-the-post's electoral incentives), and split the Alliance Vote. The National Federation Party (NFP) narrowly scraped to victory, with 26 of the 52 seats. Instead of enabling the NFP to form a government, Governor-General Ratu Sir Penaia Ganilau returned the defeated Prime Minister Ratu Mara to office at the head of a minority administration pending fresh elections held in September 1977, which the Alliance Party won. When, a decade later, a predominantly Indian-backed coalition between the Fiji Labour Party (FLP) and NFP won the general elections of 1987, the newly installed government was, within two weeks, dislodged by a military coup.

Backed by the country's Great Council of Chiefs, a new post-coup constitution was introduced in 1990, which reserved the position of Prime Minister and President for indigenous Fijians. The cross-voting (or national) seats were abolished in favour of a wholly communal-based district system. Fijians were granted 37 seats and Indo-Fijians 
27 seats, provisions which, it was hoped, would guarantee Fijian 'paramountcy'. In fact, the electoral experience under the 1990 Constitution was a shift towards a multi-party setting. The coalition between the FLP and NFP broke down, with both parties vigorously competing for the Indian vote. Coup leader Sitiveni Rabuka's Soqosoqo ni Vakavulewa ni Taukei faced considerable internal party rivalry, and was challenged by several new Fijian parties, including the Fijian Association Party and the All National Congress as well as the earlier established FNP. Ironically, Rabuka found himself dependent on FLP support to secure his majority after the 1992 polls. ${ }^{62}$ Domestic political difficulties, as well as international pressures, encouraged the Rabuka Government to embark on a mid-decade review of the 1990 Constitution.

As part of the new 1997 Constitution, Fiji introduced the alternative-vote system (AV), along with provisions for mandatory power-sharing. As with PNG's LPV system (outlined above), voters rank candidates in order of preference and, during the count, lowest-polling candidates are progressively eliminated until a victor is established. The main differences are that (1) Fiji's system requires voters who mark preferences to rank 75 per cent of candidates numerically to cast a valid ballot (whereas PNG's system requires only three candidates to be ranked) ${ }^{63}$ and (2) Fiji's ballot papers have an 'above-the-line' section enabling voters to place a simple tick endorsing a political party, thereby delegating decisions about subsequent preferences to that political party. More than 90 per cent of Fiji's voters took the latter option in 1999 and 2001, giving party officials extraordinary control over the reallocation of preference votes. The system was designed, under the influence of questionable theories about the benefits of the AV system in mitigating ethnic conflict, to encourage pre-election deals between political parties representing the ethnic Fijians and Indo-Fijians. Local parliamentarians, however, were not convinced that the AV system alone would ensure multi-ethnic government. As a result, provisions were added for mandatory power-sharing. All parties with more than 10 per cent of seats in the House were entitled to Cabinet portfolios. The widely expected result was the re-election of Rabuka’s Government, but with Indo-Fijian Opposition Leader Jai Ram Reddy's NFP henceforth playing a junior role in Cabinet.

Instead, the centrist Rabuka-Reddy coalition was defeated heavily at the May 1999 polls. The FLP, relying mainly on first-preference support from the 44 per cent IndoFijian community combined with transfers of lower order ethnic Fijian preference votes under the control of party officials, found itself with an absolute majority (despite obtaining only 32.3 per cent of the nationwide first-preference vote). The country's first ever Indo-Fijian Prime Minister, Mahendra Chaudhry, took office, at the head of a reformist coalition including several small Fijian-backed parties. Precisely one year later, that government was overthrown in a coup perpetrated by indigenous Fijian extremists, backed notably by many rank-and-file members and backbench MPs from parties whose leaders had joined the Coalition Government. ${ }^{64}$

After the May 2000 coup, the Constitution was restored by Fijis Court of Appeal, paving the way for fresh elections, again held under the alternative-vote system. At the 2001 polls, two exclusively ethnic Fijian-backed political parties, the Soqosoqo ni Duavata ni Lewenivanua (SDL) and the Conservative Alliance- Matanitu Vanua 
(CAMV), secured the largest number of seats, and formed a coalition government (despite obtaining together only 35.7 per cent of the first-preference vote). A centrist alliance that called itself the 'Moderates Forum' fared poorly. Moderate parties' preferences served instead to elect the extremist Fijian parties in key marginal constituencies. ${ }^{65}$ The FLP, reliant almost exclusively on the Indo-Fijian vote (i.e., without the preference transfers from its now largely defunct allied Fijian parties) was left with 27 seats. Unable to form a government, it nevertheless insisted on its right to inclusion in Cabinet, based on the constitutional provision entitling all parties with 10 per cent or more of parliamentary seats to participate in Cabinet. The result was a succession of legal challenges to the SDL-CAMV Government, with the courts in each case upholding the FLP's right to ministerial portfolios. The SDL responded by offering to incorporate the FLP by increasing the size of Cabinet to 36 members, so as to avoid sacking CAMV ministers and thus preserve intact its governing coalition. The FLP was to be awarded a host of minor portfolios, with controversial figures such as party leader Mahendra Chaudhry excluded from participation. Further court battles followed, culminating in the FLP finally opting for a position on the Opposition benches as scheduled elections in 2006 loomed closer.

\section{New Caledonia}

Like Fiji, New Caledonia is an ethnically bipolar society, but with a 34.1 per cent white population and 44.1 per cent Melanesian population and a more substantial 'other' grouping comprising Wallisian ( 9 per cent), Indonesian (2.5 per cent) and French Polynesian (2.6 per cent). Since the abolition of the Code de l'Indigénat in 1946, New Caledonia has not had the rigid compartmentalisation by ethnic group characteristic of Fiji. In 1951, the French National Assembly passed legislation resulting in the enfranchisement of close to 9,000 Melanesians. In response, conservatives briefly secured a 'double electoral college' system in 1952, with ethnically separate constituencies for the 80 per cent majority Kanak east coast, but this was soon abandoned. Also in 1952, the two-round (or double-ballot) system was replaced with a list proportional representation system with five electoral zones returning 25 members. ${ }^{66}$

For most of the postwar years, the New Caledonian Territorial Assembly was dominated by the multi-ethnic and pro-autonomy Union Calédonien (UC), which was able to secure Melanesian and liberal European support. Kanak calls for independence in the late 1970s, influenced by the inability of the UC to achieve much in the way of self-government, led to the formation of a variety of breakaway socialist and proindependence parties. In 1977, the UC itself adopted a pro-independence position. Most European UC members left the party during the 1970s, many joining the conservative and anti-independence settler party, the Rassemblement pour la Calédonie dans la Republique (RPCR). ${ }^{67}$ Electoral laws promulgated by conservatives in the late 1970s raised the threshold required to secure seats in the Territorial Assembly to 7.5 per cent and abolished proportional representation in the Governing Council. The objective was to exclude smaller Melanesian parties such as Parti de Libération Kanak (Palika - with 6.5 per cent of the vote in 1977). ${ }^{68}$ Instead, it precipitated their unification: proindependence groups aligned themselves behind a newly formed Front Indépendantiste 
(FI), which obtained 14 seats compared with the RPCR's 15 seats in the 1979 Regional Aassembly (the FI was renamed Front de Libération Nationale Kanak et Socialiste [FLNKS] in 1984). During the 1980s, growing social conflict including land occupations, roadblocks, assassinations, industrial sabotage and electoral boycotts culminated in the 1988 Ouvéa crisis, which resulted in the death of 19 pro-independence demonstrators and four members of the government security forces and precipitated greater efforts by political leaders on both sides to secure a negotiated settlement.

The 1988 Matignon Accord, agreed between RPCR and FLNKS leaders, included a 10-year 'rebalancing' program, entailing development projects for the majority Kanak north and the Loyalty Islands, and promised a referendum on independence a decade later. For electoral purposes, the territory was divided into three provinces, one each covering the south and north of the Grand Terre (main island) and another covering the Loyalty Islands. These returned, respectively, 32, 15 and seven members to the 54member New Caledonian Congress as well as electing members to separate provincial assemblies. Indigenous Kanaks predominate both in the Northern Province and in the Loyalty Islands, whereas all other ethnic groups reside largely in the more populous Southern Province, which is also the most prosperous region and location of the capital, Noumea. ${ }^{69}$ With substantial support from minority groups as well as European settlers and some Melanesians, the RPCR was able to obtain the largest share of the vote in the Southern Province (52.5 per cent in 1989, 46.4 per cent in 1995, 49.6 per cent in 1999), and secured significant minority support in the Northern Province and even in the overwhelmingly indigenous Loyalty Islands. ${ }^{70}$ It was able to retain control over Congress, either alone or in coalition, through the 1990s.

The FLNKS, by contrast, saw its support decline in the Northern Province (62.7 per cent in 1989, 34.3 per cent in 1995 and 22.2 per cent in 1999), owing to internal fissions centring on the coalition's longstanding leftist orientation and collaboration of senior leaders with the RPCR. The signing of the Noumea Accord in 1998 further accentuated those divisions, with the breakaway Fédération des Comités de Co-ordination des Indépendantistes (FCCI) coalescing with the RPCR to control the Congress. The Noumea Accord put back the scheduled vote on independence for a further 15-20 years, established a Senate for Kanak chiefs and provided for mandatory power-sharing, with all parties receiving in excess of six seats in the 54-member Congress securing representation in government. ${ }^{71}$ At the 2004 polls, 31 distinct lists were fielded in the three provinces, with divisions becoming particularly acute among the Melanesian-backed parties. Inability to agree on a unified list ensured that no Kanak party crossed the 5 per cent electoral threshold in the Southern Province, and all six FLNKS senators in the south lost their seats. ${ }^{72}$ Fragmentation was not confined to the Kanak parties. Jacques Lafleur's Rassemblement UMP (the renamed RPCR) saw its overall vote share fall from 38.8 per cent to 24.4 per cent, and it lost eight of its 24 seats at the 2004 polls. The newly formed centrist Avenir Ensemble secured 23.8 per cent of the overall vote (and 16 seats), and led the post-election Government. Avenir, argues Nic Maclellan, is shifting the political agenda away from divisive ethnic issues towards a greater concern with 'issues of corruption, cronyism and gender politics. ${ }^{73}$ 


\section{Repercussions of electoral laws}

The contemporary political history of the Pacific is, as we have seen, littered with misconceived electoral reform initiatives and institutional changes that had outcomes that varied markedly from what was anticipated by their architects. In New Caledonia, raising the threshold required for parties to secure representation in 1979 was intended to disadvantage radical Kanak parties. Instead, it brought them together and enabled them temporarily to enter the local government in the early 1980s. Gaston Flosse's introduction of a 30 per cent seat bonus for the winning party in French Polynesia was devised to bolster the fortunes of his Tahoerra Huiraatira. Instead, it enabled his archrival, Oscar Temaru, to take office in May 2004. Fiji's 1965-87 cross-voting system was intended to facilitate the emergence of a Malaysian-style Alliance Party. Instead, it strengthened communal party machines, which became adept at finding puppet candidates from the other ethnic group to field in the appropriate constituencies. ${ }^{74}$ The post-coup 1990 constitution was intended to entrench indigenous Fijian 'paramountcy'. Instead, coup leader Rabuka soon found himself reliant on support from the largely Indian-backed FLP to retain office. The alternative-vote system was intended to encourage moderate candidates and coalitions based on policy agreements on ethnically sensitive issues. Instead, it sent its centrist architects to a crashing defeat in May 1999, and, in 2001, facilitated victory for an ethno-nationalist coalition that included supporters of the failed coup of May 2000.

The anticipated Duvergerian interrelation between the electoral system and party polarisation did play some role in the political history of the bipolar countries, but, everywhere, other factors were of primary significance. Vanuatu's francophone/anglophone divisions, and the indigenous/settler-descended cleavages in Fiji and New Caledonia in the 1980s provided the critical impetus towards the formation of two-party systems, not the logic of electoral laws. Even the no-party systems, whether or not they used single-member districts, often witnessed loosely bipolar-style cleavages centred on distinctions between those on the Government side or on the opposition benches (for example, Tuvalu, Kiribati and Sämoa). Executive instability in such states was indicative of a tendency for government to only just secure its majority in Parliament, providing other members with the incentive to group together to plot the next no-confidence challenge (a trend that can occur in any parliamentary system, whatever the electoral system). In the bipolar and party-based territories, electoral systems worked their influence at the margin, facilitating multi-partyism in situations already prone to greater political fragmentation or entrenching bipolarity in circumstances where political allegiances were already such as to pit two sides against each other.

Nevertheless, the marginal influence was important. Electoral arrangements that served to break down polarised alignments in the political sphere eased the way to ethnic accommodation. In Fiji, inter-ethnic electoral alliances, which had become possible due to the introduction of the 25 new open or common roll constituencies in 1997, broke down after the first election under the AV system, and were in ruins after the May 2000 coup. The more centrist of the two largely Indian-backed parties, the NFP, did form a coalition 
with other 'Moderates Forum' parties in the run up to the 2001 polls, but it was emphatically defeated, and left for a second time with no seats in Parliament. ${ }^{75} \mathrm{New}$ Caledonia's political parties, including both conservatives (for most of the postwar years) and Melanesian-backed pro-independence parties (from the 1970s) had a long history of infighting and splintering. The impact of electoral incentives in promoting greater unity among Melanesian parties was evident in 1979 when the threshold was raised to 7.5 per cent. As polarisation increased in the 1980s, elections served as referenda on the independence issue, and the bipolar division became more entrenched. In the wake of the Matignon and Noumea Accords, an increasing number of parties again emerged and, as they did so, coalitions became increasingly unavoidable. Whereas Fiji, under AV, saw increasing numbers of voters line up behind ethnic political parties, one representing IndoFijians ${ }^{76}$ and the others representing ethnic Fijians, ${ }^{77}$ New Caledonia's ethnic fissures have become less marked in the wake of the electoral boycotts and violence of the mid-1980s, with centrists securing control over Congress in a multi-party coalition in $2004 .{ }^{78}$

Other technical aspects of the electoral system also influenced Pacific party constellations. Laws on party finances, crossing the floor and official designations on ballot papers served to alter parliamentary balances between independents and party-aligned MPs. Constitutional provisions for parliamentary offices for opposition or independent leaders encouraged greater coherence among MPs not in government. French Polynesia's list proportional representation system, with its 37-member Windward Islands constituency, did not encourage multi-partyism after the introduction of a 30 per cent majority seat bonus (which turned the classic proportional representation system into its opposite). Electoral thresholds in the French territories discouraged tiny parties. Split-format ballots in Fiji gave party officials an extraordinary influence over the distribution of preference votes. Mandatory power-sharing provisions regarding cabinet composition, if anticipated in pre-election party alignments, discouraged smaller parties that might diminish broader ethnic representation in cabinet. Only once all these influences are weighed up, together with the extent of heterogeneity and the electoral laws, can one establish the likely repercussions for party polarisation.

A key issue in many of the Pacific countries is not whether the electoral system encourages a two-party system or a multi-party constellation, but whether it encourages any party system at all. Single-member districts might have eased the path to the retention of no-party systems, with MPs often selected, at least in rural areas, on the basis of their position within local hierarchies or community standing. ${ }^{79}$ Yet such responses were also evident in countries with multi-member districts,such as Nauru, Tuvalu or Kiribati. The multi-member single non-transferable vote (SNTV) in Vanuatu initially coexisted with what was probably the strongest party-based system in the post-colonial Pacific, but as the independence issue faded parties splintered and independents proliferated. The rise and fall of Vanuatu's two-party-based system had little to do with the logic of electoral laws, although SNTV might have encouraged feuding politicians to fall back on regional fiefdoms. Where electoral laws had most impact in encouraging the formation of political parties was in New Caledonia and French Polynesia, but here too other complementary influences were the inheritance of strong traditions of party politics from mainland France and polarisation around the independence issue. 
Leaving aside the ethnically bipolar states (which face distinctive problems), contemporary reform objectives in most Pacific Island countries might focus on encouraging the emergence of party systems, but the primary objective is usually strengthening executive authority. In this, Sämoa's HRPP has proved most successful, having survived in office, with only one brief exception, for more than one-quarter of a century. Sämoa initially witnessed a high degree of incumbent turnover and, until 1979, had an Assembly dominated by independents. The HRPP proved able to diminish scope for parliamentary and extra-parliamentary challenges to its rule, by extending parliamentary terms from three to five years, by expanding Cabinet size and, most controversially, by use of the fruits and achievements of office to procure political support. Although the Opposition also improved political party organisation from 1982 onwards, the itu Malo (the Government or 'victorious side') triumphed over the itu Vaivai ('losing side'). Sämoa increasingly has a single executive party dominating a loosely party-aligned assembly with many 'independents'. After elections, the Government consolidates control over the assembly, by drawing hitherto non-aligned or opposition MPs across the floor. The system strengthens executive authority, but not to such a degree as to empower an authoritarian regime (although some political controversy centres on this possibility). Most importantly, the Sämoan party system was not a top-down creation of institutional engineers, but a home-grown product of shifting political forces and the decline of tamaa-äiga (ruling chiefly families) parliamentary authority during the 1970s.

Party-centred political development is not an inevitable accompaniment of human history. Pacific nations are sometimes compared with Greek city-states, ${ }^{80}$ but ancient Athens, that 'cradle of democracy', did not have a party-based system. Many Pacific states are similar in size to shire counties or town councils in metropolitan countries, which often have more fluid and personalised alignments than national parliaments or lack political parties altogether. Where domestic issues have emerged around which party systems crystallise, as in the Marshall Islands or Sämoa, these on balance probably assist effective government. But there seems to be little logic in forcing party organisation on countries such as the FSM, Palau or Tuvalu on the dubious grounds that political parties are indispensable for democracy or stability. Government instability in the Cook Islands, despite the party-centred system, indicates that legislation aimed at obliging MPs to join political parties is unlikely to be greatly effective. Where political parties are nothing more than vehicles for ambitious leaders to capture power, they inevitably remain weak and lack broad legitimacy. Elaborate institutional engineering projects are much more likely to create these types of parties than genuine watchdog parties or truly hegemonic governing parties. The notion that collective action and ideological affinity can be forced top-downwards by statute is indicative of a topsy-turvy style of thinking.

More effective reform proposals would aim instead at harnessing existing local pressures for greater choice, enhancing direct popular controls over representatives and governments, and experimenting with new checks and balances over executive authority. A greater separation of executive and legislative powers, coupled with effective popular recall systems and a strong judiciary, offers a better way of avoiding the problem of hamstrung assemblies that serve only as arenas for the pursuit of personal ambition rather than institutional experiments designed to conjure into being party-based systems. 


\section{Footnotes}

1 Duverger, M. 1954. Political Parties: Their Organisation and Activity in the Modern State. London: Methuen. pp. 217, 239; see also the discussions in Grofman, Bernard and Arend Lijphart (eds). 1986. Electoral Laws and Their Political Consequences. New York: Agathon Press; Neto, Amorim O. and G. W. Cox. 1997. 'Electoral institutions, cleavage structures and the number of parties.' American Journal of Political Science, Vol. 41, No. 1. pp. 149-74.

2 Taagepera, R. and M. S. Shugart. 1973. Seats and Votes: The Effects and Determinants of Electoral Systems. New Haven, Conn: Yale University Press; Lijphart, A. 1994. Electoral Systems and Party Systems; A Study of Twenty-Seven Democracies, 1945-1990. Oxford, UK: Oxford University Press; Taagepera, R. 1999. 'The Number of Parties as a Function of Heterogeneity and Electoral System.' Comparative Political Studies, Vol. 32, No. 5. pp. 531-48; Neto and Cox, op. cit.; Ordeshook, P. C. and Olga V. Shvetsova. 1994. 'Ethnic Heterogeneity, District Magnitude, and the Number of Parties.' American Journal of Political Science, Vol. 38, No. 1. pp.100-23.

3 Ghai Y. 1988. 'Systems of Government - 1.' In Y. Ghai (ed.), Law, Government and Politics in the Pacific Island States. Suva, Fiji: Institute of Pacific Studies, University of the South Pacific. p. 69.

4 Huntington, S. 1991. The Third Wave; Democratization in the Late Twentieth Century. Norman, OK, and London: University of Oklahoma Press. pp. 266-7. The much-debated two-turnover test finds 'democratic consolidation' in situations where the governing party is ousted by another party and that second party is subsequently defeated at the polls and gives way to the victor.

5 This was, however, often not the case during the colonial era, as Ron May points out in Chapter Five of this volume, when political parties were sometimes seen as a potential threat to foreign rule.

6 Premdas, R. and J. Steeves. 1981. 'The Solomon Islands: First Elections after Independence.' Journal of Pacific History, Vol. 16, No. 4. p. 193.

$7 \quad$ Ibid., pp. 194, 202; Macdonald, B. 1996. 'Governance and Political Processes in Kiribati.' Economics Division Working Paper, No. 96/2. Canberra: RSPAS-ANU. p. 6; Lawson, S. 1996. Tradition Versus Democracy in the South Pacific; Fiji, Tonga and Western Sämoa. New York: Cambridge University Press. p. 148 .

8 Lipset, Seymour Martin. 2000. 'The Indispensability of Political Parties.' Journal of Democracy, Vol. 11, No. 1. pp. 48-55; Schattschneider, E. 1942. Party Government. New York: Farrar \& Reinhart. p. 1; Lijphart, A. 2004. 'Constitutional Design for Divided Societies.' Journal of Democracy, Vol. 15, No. 2. pp. 96-109, at p. 102.

9 Reeves, Paul Vakatora, R. Tomasi and Brij V. Lal. 1996. 'The Fiji Islands: Towards a United Future.' Report of the Fiji Constitutional Review Commission, Parliament of Fiji, Parliamentary Paper, No. 34 of 1996. p. 310.

10 Ibid., p. 320. The way this system worked is outlined in the Fiji section below.

11 For New Zealand, see Geddis, A., 'Gang Aft A-Gley: New Zealand's Attempt to Combat "Party Hopping” by Elected Representatives', Election Law Journal, 1 (4), 2002, pp. 557-71.

12 Table 3.1, however, shows PNG as having a first-past-the-post system, since this was still in use at the 2002 polls, with AV adopted only for the following general election and intervening by-elections.

13 Solomon Islands Prime Minister Kemakeza's PAP is shown, in the Parties of the World data set used here, as having 20 MPs after the 2001 Solomon Islands elections, whereas this in fact included at least seven so-called 'shadow' members, whose allegiance was far from certain (see Fraenkel, J. 2004. The Manipulation of Custom. Melbourne: Victoria University Press. p. 137).

14 Even here, however, timing is often critical to measurement; in the Solomon Islands or Sämoa, for example, the number of seats secured by each party differs markedly depending on whether one estimates this straight after a general election or closer to the time when Parliament gathers to select a prime minister or during the subsequent process of government formation (when previously unaligned MPs tend to cluster towards the victor).

15 This section draws on Fraenkel, J. 2004. 'Electoral Engineering in Papua New Guinea; Lessons from Fiji and Elsewhere.' Pacific Economic Bulletin, Vol. 19, No. 1. pp. 122-33.

16 Standish, B. 2002. 'Papua New Guinea Politics: Attempting to Engineer the Future.' Development Bulletin, 60. pp. 28-32. 
17 Okole, H. 2002. 'Institutional Decay in a Melanesian Parliamentary Democracy: Papua New Guinea.' Development Bulletin, 60. pp. 37-40, at p. 39.

18 May, R. J., chapter in this volume.

19 In India, more defections occurred after the introduction of anti-defection legislation than beforehand. While individual defections diminished from 1985, collective defections increased in number ('Advisory Panel on Electoral Reforms; Standards in Political Life, Review of the Electoral Law, Processes and Reform options, consultation paper prepared for the National Commission to Review the Working of the Constitution, New Delhi, 8 January 2001, Section 19.1, http://lawmin.nic.in/ncrwc/finalreport/ v2b1-9.htm).'

20 Reilly, B. 1996. 'The Effects of the Electoral System in Papua New Guinea.' In Y. Saffu (ed.), The 1992 Papua New Guinea Election: Change and Continuity in Electoral Politics, Canberra: ANU, pp. 43-76; Reilly, B. 1997. 'The Alternative Vote and Ethnic Accommodation: New Evidence from Papua New Guinea.' Electoral Studies, Vol. 16, No. 1. pp. 1-11; Reilly, B. 2001. Democracy in Divided Societies; Electoral Engineering for Conflict Management. Cambridge: Cambridge University Press. pp. 58-94. For an alternative perspective, see Standish, B., op. cit.

21 Kenilorea, P. 1972. 'Political Development.' In R. J. May (ed.), Priorities in Melanesian Development, papers delivered at the sixth Waigani Seminar, Port Moresby: UPNG and ANU. pp. 24-5; Herlihy, J. M. 1980. 'Decolonization Politics in the Solomon Islands: The Model that Never Was.' In R. J. May and H. Nelson (eds) Melanesia; Beyond Diversity, Vol. 2, Canberra: ANU. p. 6.

22 Premdas, R.R. and G. Steeves, op. cit., pp. 190-202; Chick, J. D. 1980. 'Electoral Politics in the Solomons.' Pacific Perspectives, Vol. 8, No. 2. pp. 21-30.

23 Steeves, J. 1996. 'Unbounded Politics in the Solomon Islands.' Pacific Studies, Vol. 19, No. 1. pp. 133-8.

24 Reynolds, A., B. Reilly and A. Ellis. 2005. Electoral System Design; The New International IDEA Handbook. Stockholm: IDEA. Annex A. pp. 113-7, 166-73.

25 In Vanuatu, there are in fact six single-member and 11 multi-member districts, so that the former function, in effect, as first-past-the-post districts, while only the latter employ the single non-transferable vote system.

26 See Van Trease, H. 2005. 'The Operation of the Single Non-Transferable Vote System in Vanuatu.' Commonwealth and Comparative Politics, Vol. 43, No. 3. pp 296-332.

27 Morgan, Michael G. 2004. 'Political Fragmentation and the Policy Environment in Vanuatu, 1980-2004.' Pacific Economic Bulletin, Vol. 19, No. 3. pp. 40-8; Morgan, this volume.

28 See Van Trease, H., op. cit., figure 2, p. 316.

29 See Grofman, B., S-C. Lee, E. A. Winckler and B. Woodall. 1999. Elections in Japan, Korea and Taiwan Under the Single Non-Transferable Vote; The Comparative Study of an Embedded Institution. Ann Arbor: University of Michigan Press.

30 Hanlon, D. and W. Eperiam. 1988. 'Federated States of Micronesia: Unifying the Remnants.' In R. Crocombe and A. Ali (eds), Politics in Micronesia, Suva: IPS-USP. pp. 85-106.

31 Quimby, F. 1988. 'The Yin and Yang of Belau: A Nuclear Free Movement Struggles with the Quest for Economic Development.' In R. Crocombe and A. Ali (eds), ibid. pp. 113, 114; Anckar, D. and C. Anckar. 2000. 'Democracies Without Parties.' Comparative Political Studies, Vol. 33, No. 2. p. 229; Shuster, D. R. 2001. 'Palau.' In D. Nohlen, F. Grotz and C. Hartmann (eds), Elections in Asia and the Pacific, A Data Handbook, Oxford: Oxford University Press. p. 742.

32 For further detail, see Fraenkel, J. 2002. 'Strategic Registration from Metropolis to Periphery in the Republic of the Marshall Islands.' Journal of Pacific History, Vol. 37, No. 3. pp. 299-312.

33 Johnson, G. 2004. 'Marshall Islands National Election 2003 — Trends and Implications.' Paper presented at Political Culture, Representation and Electoral Systems in the Pacific Islands, PIAS-DG Conference, Port Vila, Vanuatu, July 2004.

34 Beyond the 2003 polls, rallies and public demonstrations have continued to figure as a regular feature of Marshallese political life, focused on Kwajalein rents, the compact and nuclear compensation (see 'Protestors Buck Tradition in the Marshalls', Yoke Online, February 7, 2005).

35 Macdonald, B. 1996. 'Governance and Political Processes in Kiribati.' Economics Division Working Papers, No. 96/2. Canberra: RSPAS-ANU. p. 12. 
36 In a three-member constituency with no first-round victors, the top five contest a second round. In two-member constituencies, the top four candidates contest in round two (Brechtenfeld, N. 1993.

'The Electoral System.' In H. Van Trease (ed.), Atoll Politics; The Republic of Kiribati, Canterbury and Suva: Macmillan Brown Centre and IPS-USP, p. 44.

37 Macdonald, B., op. cit. pp. 6, 19, 24; Somoza, A. 2001. 'Kiribati.' In D. Nohlen, F. Grotz and C. Hartmann (eds), op. cit. pp. 674-5.

38 Van Trease, H. 1993. 'The General Election.' In H. Van Trease (ed.), op. cit. p. 80.

39 Somoza, A., op. cit.

40 Mackenzie, U. N. 2004. 'Kiribati 2004.' National Integrity Systems, Transparency International Country Study Report. Transparency International 2004. pp. 13-4.

41 Reilly, B. 2002. 'Social Choice in the South Seas: Electoral Innovation and the Borda Count in the Pacific Island Countries.' International Political Science Review, Vol. 23, No. 4. p. 357.

42 Anckar, D. and C. Anckar, op. cit.

43 Kun, R., W. Togomae and R. Kun. 2004. 'Nauru 2004.' National Integrity Systems, Transparency International Country Study Report. Transparency International. 2004. p. 15.

44 Hughes, Helen. 2005. 'Nauru's Future, Submission to the Constitutional Review Committee, Republic of Nauru.' The Centre for Independent Studies, www.cis.org.au, accessed May 7, 2005. Nauru's counting system was computerised, and eight members of staff were employed in the Computer Bureau (Naoero Bulletin, 03/04 Special Issue, October 22, 2004).

45 Black, D. 1958. The Theory of Committees and Elections. Cambridge: Cambridge University Press.

46 In Tuvalu and Sämoa, resort to block-voting constituencies have been methods of accommodating population increase by adding extra members rather than subdividing constituencies.

47 Some nobles hold multiple titles and are therefore entitled to multiple votes.

48 Campbell, I. 2001. 'Tonga.' In D. Nohlen, F. Grotz and C. Hartmann (eds), op. cit. pp. 810-11.

49 'Niueans Vote Against Party Politics.' Fiji Times, April 2, 2002.

50 Constituencies with more than 500 voters are entitled to two members, a threshold all except one have reached.

51 Taomia, Fakavae. 2005. 'Tuvalu.' Speech given to the Asian Development Bank, Suva, May 6. 2005.

52 Hassall, G. 2001. 'Cook Islands.' In D. Nohlen, F. Grotz and C. Hartmann (eds), op. cit.

53 Crocombe, R. and J. T. Jonassen. 2004. Political Culture, Representation and the Electoral System in the Cook Islands. Paper delivered at the conference 'Political Culture, Representation and the Electoral System in the Pacific Islands', Port Vila, Vanuatu, July 2004.

54 Initially, an 'individual voters' constituency had five members, but this was reduced as numbers of voters falling into this category declined, due partly to those of foreign descent opting to join the 'territorial' (i.e., Sämoan) rolls.

55 For further details, see So'o, A. and J. Fraenkel. 2005. 'The Role of Ballot Chiefs (Matai Palota) and Political Parties in Sämoa's Shift to Universal Suffrage.' Commonwealth and Comparative Politics, Vol. 43, No. 3. pp. 333-61.

56 'Dump Under-secretaries: Le Mamea.' Samoa Observer, February 7, 2005.

57 Chappell, D. 2005. 'French Polynesia; Polynesia in Review.' The Contemporary Pacific, Vol. 17, No. 1. p. 198.

58 As Sémir Al Wardi and Jean-Marc Regnault point out ('La Crise Politique en Polynésie Française (2004-2005)', forthcoming paper, p. 2), Flosse would have won the election under the former electoral arrangements.

59 Radio New Zealand. 2005. 'French Polynesia elects Oscar Temaru President.' March 3, 2005.

60 Fijians had, since 1903, been represented only by non-elected members nominated by the Council of Chiefs, and did not secure elected representation until 1963.

61 Lal, B. V. 1988. 'Before the Storm: An Analysis of the Fiji General Election of 1987.' Pacific Studies, Vol. 12, No. 1. p. 90.

62 Lal, B. V. 1995. 'Rabuka's Republic: The Fiji Snap Elections of 1994.' Pacific Studies, Vol. 18, No. 1. p. 49; Lal, B. V. 1993. 'Chiefs and Indians: Elections and Politics in Contemporary Fiji.' The Contemporary Pacific, Vol. 5, No. 2. pp. 294-7. 
63 Hence, Fiji's system makes it much more likely than PNG's system that absolute majorities will be secured in constituencies. In PNG, ballots can be exhausted before majorities are secured. Even Fiji's system, however, does not ensure that the party that wins the election obtains a majority of national votes cast.

64 For further details, see Fraenkel, J. 2001. 'The Alternative Vote System in Fiji: Electoral Engineering or Ballot-Rigging?' Journal of Commonwealth and Comparative Politics, Vol. 39, No. 2. pp. 1-31.

65 This was often because Labour was ranked last and the SDL or CAMV were in penultimate position. As in 1999, negative ranking proved a critical determinant of electoral success in the most marginal seats.

66 Dornoy, M. 1984. Politics in New Caledonia. Sydney: Sydney University Press. p. 163; but see the slightly different account in Thomson, V. and R. Aldoff. 1971. The French Pacific Islands; French Polynesia and New Caledonia. Berkeley, Los Angeles, and London: University of California Press. p. 298. In 1957, an open list proportional representation system was adopted 'in which electors could mark their whole ballot in the order of their preference' (Thomson and Aldoff, The French Pacific, p. 305).

67 Dornory, M., op. cit., pp. 170-1.

68 Connell, J. 1987. 'New Caledonia or Kanaky? The Political History of a French Colony'. Pacific Research Monograph, No. 16. Canberra: NCDS, ANU. p. 278.

69 In 1996, Melanesians formed 96.2 per cent of the voting-age population in the Loyalty Islands, 76 per cent in the north, but only 23.4 per cent in the south.

70 McCallum, W. 1992. 'European Loyalist and Polynesian Political Dissent in New Caledonia: The Other Challenge to the RPCR Orthodoxy.' Pacific Studies, Vol. 15, No. 3. pp. 55-6n.

71 For further details, see Maclellan, N. 1999. 'The Noumea Accord and Decolonisation in New Caledonia.' Journal of Pacific History, Vol. 34, No. 3. pp. 245-52.

72 Maclellan, N. 2005. 'From Eloi to Europe: Interactions with the ballot box in New Caledonia'. Commonwealth and Comparative Politics, Vol. 34, No. 3. pp. 394-417.

73 Ibid., p. 412.

74 For a more detailed analysis, see Fraenkel, J. 2003. 'Electoral Engineering and the Politicisation of Ethnic Frictions in Fiji.' In Bastian, S and R. Luckham (eds), Can Democracy Be Designed? The Politics of Institutional Choice in Conflict-Torn Societies, Sussex: IDS, Zed Books Ltd. pp. 220-52.

75 The NFP did gain Nadi Open, but lost this after a court-ordered recount of invalid ballots.

76 The FLP secured 66 per cent of the Indo-Fijian vote in 1999, 75 per cent in 2001.

77 The SDL secured 50 per cent of the Fijian vote in 2001, with the CAMV taking another 20 per cent.

78 This section summarises the arguments in Fraenkel, J. Forthcoming. 'Fiji and New Caledonia; A Microcosm of the Global Electoral Engineering Debate.'

79 Ghai, Y., op. cit. pp. 60, 69. It might be noted, however, that there was not much sign of a decline in the party-based system in the Cook Islands when the country switched to a single-member-based system in 1981.

80 Larmour, P. 1994. '“A Foreign Flower?” Democracy in the South Pacific.' Pacific Studies, Vol. 17, No. 1. p. 49. 